\title{
Ethics and cultural identities in different contexts: an interview with Isaac Nahon-Serfaty
}

\section{Mônica Bertholdo Pieniz}

Doutora; Universidade Federal do Rio Grande do Sul, Porto Alegre, RS, Brasil

monica.pieniz@ufrgs.br

\begin{abstract}
This interview addresses the trajectory and lines of research of professor Isaac Nahon-Serfaty, from the University of Ottawa, Canada. Based on his vast experience as a consultant and researcher, discussions on ethics and cultural identities stand out, especially in the contexts of the work of communication professionals. Themes as health communication, religion and cultural diversity are important parts of this reflection.
\end{abstract}

\section{Keywords}

Ethics. Cultural identities. Health communication. Religion.

Cultural diversities.

Isaac Nahon-Serfaty (PhD) is a scholar and consultant in organizational communication, with extensive experience in the health care sector, crisis management and corporate social responsibility. He has developed a non-strategic approach to institutional communication, with emphasis on the generation of shared values. He also focuses on understanding the role of senses in our way of perceiving the world and interacting with each other, known as sensitive communication. Recently, Nahon-Serfaty enquiries about the role of the visually grotesque in public communication on a book called "Strategic Communication and Deformative Transparency", published by Routledge. He was Director of the Health Practice for Latin America at Burson-Marsteller and currently is an Associate Professor in the Department of Communication at the University of Ottawa (Canada). Twitter: @narrativaoral

First, thank you so much for having me and for sharing your experience and knowledge, Dr. Isaac Nahon-Serfaty. Throughout your career as a 
communication professional and professor, you have focused on reflecting about ethics related to health communication, multiculturalism, religion, and the grotesque in the media representation, for example. You have also dedicated yourself to international communication issues, especially regarding Latin America and Venezuela. In a way, you have been discussing and researching about ethics in different contexts. Why did you choose this research path? Can you share that with us?

Well, first, I think that there are two ways to answer this question. The first one comes more from my professional background, and the other one is more academic research-based. You know, before being a professor or researcher, I worked as a journalist and then corporate communication in PR and, again, I'm experienced as a professional in communication. And, certainly, during my career - I started very young at 18 years old and my first job was as a journalist - I always faced issues of ethics where you have to decide what would be the right way to proceed either as a journalist, as a corporate communication person, or as a PR consultant.

And then I was confronted with different kinds of situations where I needed to decide according to my conscience, according to my values, or according to my judgement. I think that's one way to look at it.

The other path is more the research academic one. There, also, you see that you are confronted. When you do research, you certainly have to follow certain ethical standards, but you also have to ask questions about the ethics of what you are doing. And I think that's why I always have, somewhat in my research - either in health communication, in PR, in strategic communication, or in any aspect of our research - there is always this element, this reflection on the ethics in terms of how this corresponds to a set of values.

And then the other question is: how far can you go, when doing communication, in terms of achieving an objective? I mean, does achieving an objective justify certain kinds of things? No, I don't think so. And that's why I think it's important to always reflect on the impact of what you are doing, or the impact of strategy, or the impact of intervention, or whatever. That's my answer.

I think I always have... I go back to my life as a practitioner, as a communication professional to think about these issues. I mean, this is not just a kind of a theoretical reflection for me or something that I look at in a very abstract conceptual way. I prefer to look at this as something that affects real life, real people in real situations and that's why I 
think it's important to always have this in mind, you know, some kind of moral horizon or ethical reflection.

Yes, I understand that. And why did you decide to discuss about religion in your research?

Well, that's also different. I'm not a specialist in religion. I'm interested in the religious phenomenon. But I have a colleague in the University of Miami, Donn Tilson, who works in religion.

His specialty is the connection between religion, and communication, and PR. And he looks at religion as a way to understand what values should drive any kind of public relations or communications strategy initiative. He proposed to me when I moved here, to develop a joint project about religion and communication. He invited me to a seminar he organized in Miami to talk about this, and then he was interested in organizing a conference here.

\section{That was in 2009, right?}

Exactly. Then we organized it. I organized a conference, and after that conference we published the book. Most of the papers presented in that conference are there, not all of them, and some others. And that's why I became interested in religion. But it's more about, again, questions of diversity, of coexistence. It's not religion per se, but questions related to the diversity of cultures and coexistence that interest me.

So, in 2009 you organized the International Workshop on Cultural Dialogues, Religion and Communication with your colleague from Miami, Donn Tilson, and others. Five years later, in 2014, you and Dr. Rukhsana Ahmed edited the book New Media and Communication Across Religious and Cultures with different articles, but regarding the same subject.

It focused on the idea that religion, as a social and cultural phenomenon, is back. It's taking center-stage again, in society.

Yes. In society in general. 
In general, but also in societies like the Canadian society, in Europe, and all the societies that believe that religion was a subject of the private lives of citizens and should be kept outside the public sphere. And then what we have seen in recent years, for different reasons, is that religion is back at the centre-stage of public life. And that's why we organized this conference: to discuss how in countries such as Canada or other countries - how this diversity, in terms of religion and cultural diversity, should be approached - particularly from my communication point of view.

\section{That's interesting. And how would say you perceive these discussions nowadays?}

Well, I think it's still relevant. I think most of the issues discussed at the conference and in the book are still relevant today both from a not-so-positive perspective - because religion is a source of conflict and tension - but also as a religion or some of the foundations of religions as a way to promote coexistence and dialogue. They are still relevant at many levels, I mean, in international politics, religions are still playing a role. If you look at societies internally, religions are still playing a role in terms of the respect of the other, etc. And if you look at the issues associated with violence, some groups use religion to justify violence: terrorism. So, I think it's still relevant. Most of the papers published in this book are very current today.

\section{On that book, you explain the bill of religious neutrality discussed in the} Quebec government.

Quebec approved a law that bans the use of religious symbols in the government and public education. This is very particular to Quebec, different from other provinces in Canada... Now this bill, this law has been contested in the Supreme Court of Canada.

It's very controversial. But according to some polls, about 70\% of Quebeckers support this law, but in the rest of Canada people are not that open to supporting this kind of restriction or guidelines in terms of religious symbol. There are two different ways of looking at the issue: one, the Canadian multicultural way that says, "Okay, we accept everybody and you can wear whatever you want or say whatever you want or know whatever you want, but you can't pray the way you like or you can't wear religious symbols or things that are part of your tradition". That's the Canadian way of looking at things. In Quebec they say, "Yes, you can do that, but you cannot be, or you cannot wear this kind of 
symbol if you are representing the state or a public institution, because public institutions and the state are not confessional, so we don't want to give the impression that we are, in any way, supporting or backing a religious point of view or whatever". It's very controversial.

But the only thing that I would say is that this is showing that religion is still very relevant nowadays, and that's something you cannot avoid, I mean, even if people identify themselves as being non-religious, for example, or they don't have a particular attachment to religion. What you cannot deny is that religion - because of immigration, because of geopolitics, because of many reasons - religion is an important factor now when it comes to discussing society, politics, culture, communication. Whatever you want to discuss, the religious factor is there - and you cannot ignore that.

\section{Yes. And what do you think about the expression secular illusion? Not just in Canada, but in Latin America, for example.}

Well, in Latin America it's not that evident because religion has always played a very important role in different ways. You have some countries that define themselves as being more Catholic and more formal in terms of the way they follow the Catholic religion. Then you have other countries that are officially, or at least the majority of people are Catholic, but then you have all the religions kind of progressing - like the evangélicos in Brazil and, certainly, the afro-brazilian religions like Candomblé. In Latin America, I think, it's clear that religion is part of society life and nobody denies that. And sometimes the border, you know, between secularism and religion is not clearly defined. I think you have seen that in Brazilian politics recently.

And in all the cases, you have all this invocation to God, to a certain set of values, etc. But that's Latin America. In North America, in the United States, religion has also somewhat played a role in politics, but with the idea that religion should be separated, should be different from government and the state. This was the secular illusion. The secular illusion was to maintain a separation between religion as a private practice and religious in the public life. I think it's important, but it's not that easy to keep this division between religion and the state. And now, what we are experiencing is that now the state is somewhat obliged to intervene: either to guarantee the freedom of religion in some cases; or in other cases, to limit the freedom as is the case of Quebec.

In the Canadian context, for example, could the interaction among different cultures generate some form of hybrid culture? 
Well, I mean, that's part of human history in general. In the long run, the history of humanity is some kind of history of métissage, of hybridity. In the long run, that's clear. If you think about the arrival of Columbus in America, we are what we are somewhat because some kind of métissage of hybridity process took place. And I think there is no way you can stop that. There is one way if you have a very narrow-minded perspective of the world where people will stay in one territory, and they won't be able to move.

But the history of humanity is the history of human movement, of migrations, of encounters, of conflicts also certainly. That reality is the base of any kind of métissage of hybridity. And I think that's what we're seeing in Canada now somewhat. That's what we have seen in Latin America, with issues of discrimination and segregation. I'm not saying that it was perfect, but I would say that, at that level, maybe Latin America has achieved again, with issues, with limitations, with problems - some level of hybridity that's more inclusive than other societies, but still, I mean, it's an issue. You certainly have discrimination, you have segregation, you have stigmatization of certain groups. If you look at societies here with a big African influence - like the Brazilian, Colombian, or Venezuelan population, then you still have problems of discrimination there. If you look at societies with a big aboriginal population, like Peru, Bolivia, Mexico, Guatemala, you will also find issues there. I would say that the reality, in the long run, is that all societies will be, at some point, a mix of people coming from different backgrounds. That's life, I mean, I don't see how this could be different.

Moreover, the religious identity is also important when it comes to health communication research and campaigns, as was shown in your research with Professor Mahmoud Eid, for example. You have a vast experience in health communication, the marketplace and academic research. Considering that, how would you explain the importance discussing cultural identities and stereotypes for ethics in health communication related by religion, race, gender, age, ethnicity, geography, sexual orientation, abilities, physical appearance, or social status, for example?

Well, I mean, the first thing to say about this is there is no way you can try to understand health communication - I mean, if you are a communicator of health, illnesses, and health problems - without considering all these factors because everything related to 
health comes from or has a very emotional element. We don't approach these issues as human beings in a rational way; there is always an element of emotion because our lives are at stake or the lives of the people we love and care for are at stake. These emotional factors are also influenced by our values, our background, our religion, our past experiences, our beliefs, etc. And diversity is very important because you will have to deal with different people that will look at these issues differently based on their background, religion, gender, whatever. And that's why diversity is so important in this case. I mean, I could give you a scientific explanation of why that is: that this is caused by a virus and that, in order to avoid the disease, you should do this; or in order to treat the disease, you should do this; or in order to find a cure, you should do this. This is a very systematic, rational way, but we know that this is not the way you're going to process information. There is an element of rationality, yes. But there is also an element of emotion associated with that. And that element of emotion is mediated, is always under the influence of the values of people, their beliefs, their religions - certainly, that's obvious. In some cases, for example, you have some religions where they won't allow doctors to do some procedures on patients, for example, to give blood to someone, or to undergo an organ transplant, or whatever - that's an important element that should be taken into account.

Yes.

You cannot ignore that.

Yes. Your research on breast cancer and pharmaceutical issues is very interesting. I want to focus on that for a bit and talk to you specifically regarding the research project about women's breast cancer in Latin America. Which are the main points related to ethics among the stakeholders considered in that action, especially in Venezuela, where you researched? And how was the process to create a code of ethics for the NGOs? How was the experience of having a practical outcome from your research?

I think that the most important thing we were able to accomplish there is that we were able to help a group of women fighting breast cancer in Venezuela, a country that was already facing all kinds of issues in terms of lack of services, lack of medication, a highly 
polarized society politically, etc. We were able to help them, to help these women to improve, I would say, their skills in order to communicate what they needed, what they wanted, and what they were fighting for. I have a very interesting example of that from an ethical point of view. Unfortunately, my colleague who worked with me, Mahmoud, he passed away a few years ago.

\section{Oh, I'm sorry to hear that.}

Yes. He was the one who developed the code of ethics, actually. So, he was in charge of that part. He worked with some students here, and he developed a code of ethics for the organization. But I think, for me, the most important learning or outcome of that research was that these women - some of them - gained in terms of confidence and in terms of selfesteem. That's very important in order to be a spokesperson of a cause like the prevention and treatment of breast cancer. And I have one example that shows the impact of the project. We worked with women coming from different parts of Venezuela. And if you are outside Caracas, if you start going outside Caracas, in some areas of the country, the situation is very difficult because you don't have access to a hospital, you don't have access to treatment. And if you need the treatment, then you should go to Caracas, and that takes time and money in order to get your treatment. And you're going to spend a few days there without your family. It's a very difficult situation. And a lady who came from - you don't know Venezuela - a small town called El Sombrero. It's in the Venezuelan plains where they don't have anything, and they practically don't have anything.

Actually, she was there during the five years of the project. Every time we did something, like a workshop, she was always there with us. And I remember the first workshop she was there, we asked people around the table to present themselves and explain why they were there, what they were doing, etc. in terms of fighting breast cancer. I told her, "Okay now, it's your turn, please". And she couldn't say anything, she just started to cry. She couldn't articulate a word, I mean, it was so emotional for her that she was crying, and crying, and crying.

And even if you wanted to say something, she didn't know how exactly. And one thing that we did during those five years of the project was that we were working with them in order to improve their communication skills, improve doctor-patient communication, improve their relationship with the media, etc. And I remember that our third workshop was based on the idea of developing a common vision about breast cancer that became a declaration actually - you can find it on the Internet. 
I asked the same lady, "What's your view?", because we were discussing some policy issues. And she was able to articulate her position in a very clear way. She was very selfconfident and very clear and powerful in her argument. When I saw that change - that same person two years before had not been able to express her views because of all the emotional issues attached to that, and she became someone who was very clear and strong in her communication. That's an important change because you're empowering that person, in order to go back to the field and become a spokesperson for the cause and be able to fight for the rights. From an ethical point of view, that's the main accomplishment, I would say. I mean, I'm just using that example, but I can give you other examples of all the participants there.

And that, I think, was the main accomplishment of that project. If that had been my only accomplishment in the project, it would've been enough for me.

\section{During five years?}

Yes, we did different activities with the same group of women and worked with different stakeholders: doctors, government, the media, researchers.

\section{That's very interesting. And was it a multidisciplinary team?}

Yes, absolutely. I mean, we were the two principle researchers and investigator Mahmoud Eid, and I - but we also worked with different partners: doctors, sociologists, people from the industry, and particularly with these women. We had different grants from the Canadian Institute of Health Research.

\section{And from the private sector as well.}

Yes. We also had the support of the private sector. The organization was the main NGO behind the project and it's still functioning.

\section{How was the code of ethics received by the NGOs and the public? I believe you probably built it together.}

Yes. I think, first, it was well received. But there is something more important there: I think the question is that, with this code of ethics and the document on policy that we were able to develop at the end of the project, we were able to give more visibility to these organizations. We helped them to gain visibility and to be a stakeholder when it comes to 
talking about the rights of the patients or the healthcare policy. Again, in a country where it is very difficult to have access to treatment or even to have access to the Ministry of Health or to healthcare officials. But I think what they gained with all this project, including the code of ethics and the policy document, is that they were able to move their codes forward.

This is the most important, for sure. Okay. Throughout this research and all your experience of ethics in the health communication area, what kind of ethical dilemmas have you faced in this research? What kind of ethical dilemmas do you face or perceive in the pharmaceutical marketing area, and also in the breast cancer area?

First, pharmaceutical marketing is a highly problematic area in terms of ethics. Why? Maybe now it's more regulated. But ten or fifteen years ago, pharmaceutical corporations used all kinds of techniques and tactics in order to promote the problems among physicians and gave them all kinds of incentives - sometimes directly and paying them to promote the prescription of a drug or, other times, with indirect incentives like benefits, like paying for the conference, for example, or sponsoring their participation in international congresses. That has changed. I think that started to change because, now, the industry is more regulated in general - in the United States, in Canada, in Latin America. But there are still a lot of ethical issues in terms of how far the industry can go when they promote one particular medication. The other thing is about transparency.

\section{That was the next question... Perfect.}

Transparency because of the industry... it's a question we can ask regarding the disclosure of information: should the companies disclose information to the public, such as the side effect of products or potential harm caused by them? That's another question.

In principle, they have an obligation to do so. Again, because of regulation, the laws, and different regulatory organs in the countries, they have to disclose that information to the public. But, certainly, there are some gaps there. So, I don't think transparency is always the case. That's another question.

And then there is the third element that is now becoming more and more important: the environmental impact of these industries. Chemical industries, for example, produce a lot of waste, etc. So, what are they doing in that regard to become more environmentally friendly and clean industries? And that's the other question. 
I should say also that the pharmaceutical industry has had some progress in that regard in terms of marketing and transparency, and maybe in terms of the environmental impact. But it still very problematic because at the heart of the industry, there is the issue of human life. And anything that has such an impact on human life is problematic from an ethical point of view. It's almost unavoidable. It's a matter of cost-benefit versus respecting the right of people to be informed, to be treated with dignity, and to be protected from harm, etc. It's a delicate balance, and it's not easy to achieve.

\section{You have more than $\mathbf{2 5}$ years of experience in this field, right? And during} this time, how did you see the importance of communication professionals or public relations professionals in the area of health communication in general?

Well, first, in a practical way, they are becoming more and more important because the industry relies on them in order to promote their brands, their products, their activities. That's clear. I will say that, somewhat, the foundation of these industries is related to some kind of communications activity - either from a marketing point of view, from a PR point of view, or a corporate social responsibility point of view. They rely on these. Why? Because, first, they need to promote their products, they need to promote their activities, they need to influence certain stakeholders, they need to work with patients, they need to work with doctors - and all these activities require a form of communication. That's from a practical point.

And then the professional should decide how far she or he can go in terms of communicating certain things. And that's a question that is more related to the values and the convictions of the person - beyond the fact that, also, that person should respect the law. And that's a more personal thing. As a professional, what would you do when confronted with these dilemmas, with these issues? Is everything permitted when it comes to promoting a new drug? Or is everything permitted when it comes to having an activity with doctors or patients? That's the question that every professional should ask before deciding what he or she would do.

And I think that's the main problem of the industry in general, of the healthcare sector in general: you don't always have a clear answer of what to do or what not to do. It depends on the situation, on the context, on the people affected by this decision, etc. 


\section{What would you say is the role of technology in this discussion?}

Well, first, technology in communication is becoming more and more important. That's an issue. Because, again, we are talking about issues of transparency, truthfulness, accuracy - of truth even. And then in a highly fragmented media landscape where you have all kinds of people talking about health - those who are qualified and those who are not you have people presenting different views, for example, about vaccination (those who are for and those who are against). And that, among other reasons, is why they can do that because of technology. And then you have all the things happening, you know, in terms of research in healthcare, in pharma associated with artificial intelligence, algorithms, the idea of personalized medicine, the idea that they can offer you a treatment that's good for your genetic profile or whatever. I mean, it's such a complex thing that but, certainly, in communication, particularly, it's making things even worse from an ethical point of view.

Because you are confronted with more views about an issue or more opinions about an issue and how to deal with that. How do you play a role where you are the one clarifying and making things more accessible to people, etc.?

\section{Do you still feel motivated to keep this research about ethics and communication and health? What is your perspective in that?}

Well, I always go back to it. I mean, it's kind of the ending point, if you will, of the rival point of any research. I mean, I can discuss about strategy, I can discuss about technology but, in the end, I also consider the ethical issue. Always. I mean, there is no escape from ethics when you think in terms of communication. There was a very famous Venezuela communications scholar who passed away recently, unfortunately, Antonio Pasquali - he was well known - who said that there is always a moral dimension in the fact that we're communicating. You cannot escape that because it's the foundation of all human relations. Communication is the foundation of any kind of connection between human beings. And then how can you look at this without any kind of ethical consideration?

We are in a world where people communicate from different backgrounds, different cultures. Different regions communicate more and more among themselves. It's not a question of belief - it's a reality. It's a fact. And then what are you going to do? Are you going to stay closed in your country and use the Internet to hold communication with other people? With that, you are going to end this idea of cosmopolitanism. It's absurd. It's a fact. 


\section{What is the responsibility of communication professionals when dealing}

\section{with ethics in culturally diverse environments?}

I always tell my students that they have the impression that communication - when they are here at school doing their undergrad studies or even a Master's- in the end, it's not that important. They think that it's not like you're a doctor or an engineer, or someone who can really have an impact in my life, you know. Like when you are a doctor, and you don't know what to do, or if you don't do the right thing, you can end up killing someone. Or if you are an engineer and you don't know how to do calculations, then a building can collapse and, again, you can kill a lot of people. I mean, they think that this is not that important, at the end of the day, what we do here - which is a totally stupid way of looking at things because it's actually the opposite.

I think we also have a big responsibility because whatever we say and communicate can have an impact on the lives of people. It can have an impact in terms of what they do, in terms of what they believe, in terms of how they react, how they connect with other people, etc. And I think that's the main responsibility: to understand that what we are doing has the potential of doing good or bad - just like anything in life. But we have access to means of communication that potentially can have these huge impacts on people. I think it's something that we should always keep in mind - that's our main responsibility. Whatever we are going to say, to write, to convey has a huge implication in the lives of people. Maybe sometimes we don't see it. Maybe you can think, "Okay, what I'm doing is not that important". But at the end of the day, potentially, it is important, yes, because you know how someone can react to your message or what people in need can do with that message. I've seen many things in my career in communication where people say, "Well, this is not that important". And, in the end, it's important for one person because that person learned something about how to treat a disease, or how to prevent something, or how he or she can do in order to get access to treatment. I've seen that many times in my life. And that implies a lot of responsibility because you should always be aware of that potential of doing good or bad.

\section{Referências}

NAHON-SERFATY, I. \& AHMED, R (editors). New Media and Communication Across Religions and Cultures. IGI Global: United States Hershey, Pennsylvania, 2014 (328 p.).

NAHON-SERFATY, I \& EID. M,. Women, Polarization and Communication for Social Change: Breast Cancer Policy in Venezuela. In: MAO, Y., AHMED, R. Culture, Migration, and Health Communication in a Global Context. Routledge: United States, New York, 2018 (191-213). 
NAHON-SERFATY, I. \& EID, M. Risk, Activism, and Empowerment: Women's Breast Cancer in Venezuela. International Journal of Civic Engagement and Social Change, Volume 2, Issue 1, 20015 (43-64).

NAHON-SERFATY, I.; AHMED, R.; EID, M. Multi-cultural, Multi-ethnic, and Multi-faith Communication. Global Media Journal - Canadian Edition, Volume 4, Issue 1. January 2011 (1-4).

NAHON-SERFATY, I \& EID. M. Transparency in Direct-to-Consumer Pharmaceutical Marketing: Crucial Ethical Standards. Review Journal of Integrated Marketing Communications. Volume 7, number 1, 2008 (6-14).

\title{
Ética e identidades culturais em diferentes contextos: uma entrevista com Isaac Nahon- Serfaty
}

\begin{abstract}
Esta entrevista aborda a trajetória e as linhas de pesquisa do professor Dr. Isaac Nahon-Serfaty da Universidade de Ottawa, no Canadá. A partir de sua vasta experiência como consultor e pesquisador, ganham destaque as discussões sobre ética e identidades culturais, especialmente nos contextos de atuação dos profissionais da comunicação. Os temas comunicação para a saúde, religião e diversidades culturais são partes importantes desta reflexão.
\end{abstract}

\section{Keywords}

Ética. Identidades culturais. Comunicação para saúde. Religião. Diversidades culturais.

Recebido em 14/02/2020

Aceito em 10/03/2020 